\title{
Risk Disclosure Patterns among Jordanian Companies: An Exploratory Study during the COVID-19 Pandemic
}

\author{
Fawzi A. Al Sawalqa ${ }^{1}$ \\ ${ }^{1}$ Accounting Department, Business Faculty, Tafila Technical University, Tafila, Jordan \\ Correspondence: Fawzi A. Al Sawalqa, Business Faculty, Accounting Department, Tafila Technical University, P. \\ O. Box 179, Tafila 66110, Jordan.
}

Received: July 15, 2020

Accepted: August 19, 2020

Online Published: August 24, 2020

doi:10.5430/afr.v9n3p69

URL: https://doi.org/10.5430/afr.v9n3p69

\begin{abstract}
This current exploratory study comes at a critical time to determine the risk disclosure pattern of Jordanian companies during the COVID-19 pandemic. In particular, Jordan Securities Commission (JSC) asked Jordanian listed companies to prepare and send disclosure reports to include the effect of the COVID-19 pandemic on their activities in terms of material events, operational activities and the decisions of board of directors during the period of disclosure suspension extending from March 18, 2020 to May 5, 2020. Based on the non-financial companies that listed on the first market of Amman Stock Exchange (ASE), the study found that the entire study sample (100\%) did send the disclosure reports to JSC. The extraction process resulted in 20 risk items distributed over five risk categories. The results show that the average disclosure level is $65.6 \%$, with the operational category ranked first and followed by investor relation category, financial category, strategic category and finally the market category. Results also show that those companies that were suspended completely during the COVID-19 pandemic provided risk disclosures in all categories. Decision-makers and researchers should put more emphasis on the five risk categories that presented in the current study especially during the crisis time period. In addition, the current instructions of mandatory disclosure should be amended and the risk disclosure behavior of Jordanian companies should be changed. The study offers many opportunities for future studies.
\end{abstract}

Keywords: COVID-19 pandemic, risk disclosure, operational risks, financial risks, investor relation risks, strategic risks, market risks, Jordan

\section{Introduction}

Not Like other crises, the COVID-19 pandemic has impacted all the aspects of life. Its effect was clearly observed on the economy, health, education, tourism, and it went beyond that to affect the social life and to prevent even the movement of people for a period of time. Therefore, it can be argued that the COVID-19 pandemic is one of the most severe crises that passed on mankind. In general, crises have a major impact on reshaping the economies of many countries in a way that prepares them for any coming surprise (MacDonald, 1998). In this context, Gulzar et al. (2019) performed a study to determine the effect of global financial crisis on the emerging Asian markets before, during and after the crisis for the period from July 2005 to June 2015. The results of the study indicated that U.S. stock market has impacted emerging Asian stock markets during the three time periods to a considerable extent.

The current study is exploratory in nature and focuses mainly on the level and nature of risk disclosure at a critical stage, which gives it preference over other studies in offering an early reference about the impact of the COVID-19 pandemic on risk disclosure pattern. In addition, the study is conducted using services and industrial non-financial companies listed on the first market of ASE in exceptional circumstances (Marzouk, 2016). The justification for selecting the first market is that such market is subject to some strict listing requirements in comparison with the second market (Saadi-Sedik \& Martin, 2006), which contributes in the reliability of collected data.

In respect to Jordan, the COVID-19 pandemic was led to a complete paralysis in the country at a certain time, which forced the government to activate the National Defense Law No. 13 of 1992 to run the daily affairs of people. In March 16, 2020 the government suspended the trading in ASE from March 17, 2020 until May 9, 2020 and resumed it on May 10, 2020 with some new procedures including for example reducing trading periods. According to the general government finance bulletin for May 2020, the decline in Jordanian domestic revenues for the first four months of 2020 has reached JD 569.1 million (21.3\%) against the same period of 2019 due to the COVID-19 
pandemic, which led to a fiscal deficit of JD 694.9 million in the general budget during the first for months of 2020 against JD 304.1 million for the same period of 2019 (MOF, 2020).

This study comes as a preliminary attempt to explore the nature of the risk disclosure that Jordanian companies focused on during the disclosure suspension period that is specified by JSC from March 18, 2020 to May 5, 2020. The risk disclosure has its roots in the accounting literature as it is linked with crises in the first instance. For example, the 2008 financial crisis was characterized by its sudden occurrence, which forced financial firms to put more emphasis on the risk disclosure quality (Asongu, 2013). In addition, IFRS 7 and Basel II have contributed significantly in enhancing the quality of risk disclosure (Höring \& Gründl, 2011). Furthermore, several theories have been employed in investigating the voluntary risk disclosure such as agency theory, signaling theory, political cost theory, capital need theory, and legitimacy theory (Dey, Hossain \& Rezae, 2018), while the mandatory risk disclosure has been governed by several legal actions. Oliveira, Rodrigues and Craig (2013) findings indicated that reporting risk information is done just to reduce the agency costs and asked the decision-makers to put more emphasis on disclosing risk information to enhance transparency. This is because disclosure of current and expected risk information is directly contributed in supporting the confidence of the current and potential shareholders in the firm and promoted the transparency in the business market. Despite that, previous studies in this area have shown a noticeable low level of risk disclosure (e.g. Lajili \& Zéghal, 2005; Al-Shammari, 2014., Domínguez \& Gámez, 2014; Ellili \& Nobanee, 2017; Dey, Hossain \& Rezae, 2018). This may be justified based on the potential high costs of such disclosures, and the difficulty in identifying risks effectively (Lajili \& Zéghal, 2005). However, there is a close relationship between full transparency in risk disclosure and the strength of financial markets (Deumes, 2008) and the investment selection process (Domínguez \& Gámez, 2014). This is because one of the main factors that contribute in expanding the scope of risk disclosure is crises (Hemrit \& Ben Arab, 2011).

In light of the scarcity of studies that specifically addressed risk disclosure issue during crisis periods, the current study is exploratory in nature (e.g. Lajili \& Zéghal, 2005; Lungu et al., 2011; Höring \& Gründl, 2011) and comes to be one of the first studies to investigate the effect of the COVID-19 pandemic on risk disclosure pattern from March 17, 2020 until May 9, 2020. In particular, the current study has two main objectives:

1. To investigate the extent to which Jordanian listed companies responded to the disclosure requirements of JSC during the COVID-19 pandemic.

2. To describe the risk disclosure pattern of Jordanian listed companies during the period of disclosure suspension.

In respect to the response to the request of JSC, results show that the entire study sample sent the disclosure reports to JSC and were also disclosed the valuable information about the effect of the COVID-19 pandemic.

\section{Jordan Securities Commission Procedures during the COVID-19 Pandemic}

In March 20, 2020 the defense ordinance No. 2 for 2020 is declared by Jordanian government in accordance to National Defense Law No. 13 of 1992 to prohibit the movement and roaming in all over the country from March 21, 2020 until further notice due to an increase in cases of infection with the Coronavirus. Thus, the work has stopped in the various economic sectors in the country. In March 16, 2020 the government suspended the trading in ASE from March 17, 2020 until May 9, 2020 and resumed it on May 10, 2020 with some new procedures.

However, JSC extended the legal deadline for listed companies to provide the commission with annual reports for year 2019 until June 15, 2020, and the legal limit to provide the Commission with the first interim reports for the year 2020 until July 16, 2020 (JSC, 2020). Accordingly, in May 5, 2020 JSC asked the listed companies to perform the following (JSC, 2020):

1. Disclose all the material information and events that the company went through during the period of disclosure suspension extending from March 18, 2020 to May 5, 2020 as a result of the COVID-19 pandemic.

2. Prepare an initial report about the effect of the COVID-19 pandemic on the operational activities.

3. Disclose any important decisions that have been taken by the board of directors during the suspension period, particularly those related to the dividends of cash or free shares.

The request of JSC was based on Article (8) of the Instructions of Issuing Companies Disclosure, Accounting and Auditing Standards for the Year 2004. Article (8) outlines all the possible risky issues that firms should disclose in some details. Paragraph (A) of Article (8) outlines the changes that may be taken place in the assets, obligations, capital, credit rating, products, ownership, and the justification for such changes, paragraph (B) focuses on reporting the details of major transactions, paragraph (C) focuses on disclosing for nonrecurring events and transactions, paragraph (D) focuses on reporting any extraordinary events such as fires and earthquakes, paragraph (E) focuses on 
reporting any material losses, paragraph (F) focuses on disclosing the decisions of board of directors, paragraph $(\mathrm{G})$ focuses on reporting the decisions of general assembly, paragraph $(\mathrm{H})$ focuses on reporting the invitation for general assembly meetings, paragraph (I) talks about the structure of board of director, paragraph (J) focuses on disclosing any information related to the discontinuation of the activities of firms and the justification for such discontinuation, and finally, paragraph $(\mathrm{K})$ focuses on disclosing any information about the event that may affect the financial position of any firm (JSC, 2019).

However, the government decided on May 7, 2020 to resume the trading in ASE by May 10, 2020 and the board of ASE took several procedures including determining the percentage of increase and decrease for all securities by $2.5 \%$ daily, instead of 5\% with a minimum limit of $0.01 \mathrm{JD}$ and decreasing the trading time to be one hour instead of two hours for the listed securities (ASE, 2020). On May 28, 2020, the board of ASE decided to return back to the 5\% and to two hours trading as of May 31, 2020 while keeping the minimum tick size at 0.01 JD (ASE, 2020). Table (1) shows the main procedures that have been taken in respect to the trading in ASE during the COVID-19 pandemic until May 28, 2020.

Table 1. The main actions that were taken in respect to the trading in ASE during the COVID-19 pandemic

\begin{tabular}{|c|c|c|c|}
\hline $\begin{array}{l}\text { Date of } \\
\text { decision }\end{array}$ & Effective date & Decision/Action & $\begin{array}{l}\text { Decision } \\
\text {-maker }\end{array}$ \\
\hline $\begin{array}{l}\text { March 16, } \\
2020\end{array}$ & $\begin{array}{l}\text { March } 17, \\
2020\end{array}$ & Suspending the trading in the ASE from March 17, 2020. & $\begin{array}{l}\text { HE the Prime } \\
\text { Minister }\end{array}$ \\
\hline \multirow[t]{2}{*}{ May 4, 2020} & & $\begin{array}{l}\text { 1. Extending the legal deadline to provide the Commission with annual } \\
\text { reports for the year } 2019 \text { until June } 15,2020 \text {. }\end{array}$ & JSC \\
\hline & & $\begin{array}{l}\text { 2. Extending the legal limit to provide the Commission with the first } \\
\text { interim reports for the year } 2020 \text { until July } 16,2020 \text {. }\end{array}$ & \\
\hline \multirow[t]{4}{*}{ May 4, 2020} & May 5, 2020 & JSC asked the listed companies to disclose the following : & JSC \\
\hline & -May 9, 2020 & $\begin{array}{l}\text { 1.All material information and events that the company went through } \\
\text { during the period of disclosure suspension extending from March 18, } \\
2020 \text { to May 5, } 2020 \text { as a result of the COVID-19 pandemic. }\end{array}$ & \\
\hline & & $\begin{array}{l}\text { 2. An initial report about the effect of Covid- } 19 \text { pandemic on the } \\
\text { operational activities. }\end{array}$ & \\
\hline & & $\begin{array}{l}\text { 3. Any important decisions that have been taken by the board of directors } \\
\text { during the suspension period, particularly those related to the dividends } \\
\text { of cash or free shares. }\end{array}$ & \\
\hline May7, 2020 & May10, 2020 & Resuming the trading in ASE by May 10, 2020. & $\begin{array}{l}\text { HE the Prime } \\
\text { Minister }\end{array}$ \\
\hline May 7, 2020 & May 10, 2020 & $\begin{array}{l}\text { Taking several procedures including determining the percentage of } \\
\text { increase and decrease for all securities and decreasing the trading time at } \\
\text { ASE. }\end{array}$ & $\begin{array}{l}\text { The board of } \\
\text { ASE }\end{array}$ \\
\hline $\begin{array}{l}\text { May } \\
2020\end{array}$ & May 31, 2020 & $\begin{array}{l}\text { Returned back to the original procedures in respect to percentage of } \\
\text { increase and decrease and trading time at ASE. }\end{array}$ & $\begin{array}{l}\text { The board of } \\
\text { ASE }\end{array}$ \\
\hline
\end{tabular}

\section{Literature Review}

According to Höring and Gründl (2011) prior studies on risk disclosure have taken three types. First, the descriptive studies which focused mainly on the level and nature of risk disclosure. Second, those focused on the usefulness of risk disclosure and finally, those interested in testing the determinants of risk disclosure. The current study is exploratory in nature and tries to describe the risk disclosure pattern during a critical period of time. Therefore, it is interested mainly in investigating prior studies that focused mainly on developing disclosure models and indexes during and after crises.

Lajili and Zéghal (2005) found that the disclosed risks in the annual corporate repots of Canadian companies for the year 1999 distributed over nine categories including "financial, market, environment, government regulation, operational, supplier, natural resources, political, technology, weather, seasonality and cyclicality". The authors' findings indicated that $76 \%$ of Canadian companies did report risk information, with much emphasis on the 
qualitative ones and the most frequently disclosed cited categories were financial, commodity and market risks Höring and Gründl (2011) developed a risk disclosure index from 45 items along seven categories including "risk overview, underwriting risk, market risk, credit risk, operational risk, and other risks" to measure the level and determinants of risk disclosure among 31 European insurance companies. The authors focused on the development of the risk disclosure trend for the period from 2005 to 2009 and found a notable improvement in the level, location and quality of the risk disclosure. For example, the authors found that $86 \%$ of insurance companies did report risk information in 2009 comparison with only 57\% in 2005. Findings also revealed that risk overview and operational risk were the most improved categories over time. Madrigal, Guzmán and Guzmán (2015) performed a study to identify the determinants of risk disclosure in terms of the level and quality among 35 listed Spanish companies for 2009. The authors developed a risk disclosure index using the content analysis and focused mainly on the risk disclosure at corporate governance report. The risk disclosure items were distributed over 8 categories including "internal environment, objective setting, events identification, risk assessment, risk response, control activities, information and communication and monitoring". The results indicated that size, industry and level of risk were linked positively and significantly to the level of risk disclosure. Domínguez and Gámez (2014) performed a study to identify the level of risk disclosure and the main determinants among the listed Spanish companies for the period from 2007 to 2009. The authors developed a risk disclosure index including both the voluntary and compulsory items. The compulsory items distributed over three categories including "credit, liquidity and market", while the voluntary items were distributed over five categories including "operational, business, environmental, reputation and country risks". These categories were allocated to five main groups including "basic characteristics of the risk, risk management policy, information about risk coverage, methodology used to measure the risk, quantification of the risk during the economic year and information about future risks". In respect to the compulsory categories, the most common disclosed items were those related to the basic characteristics of the risk and the least disclosed items were those related to the future risks. In respect to the voluntary categories, the most disclosed items were related to basic characteristics and risk management policy, while the least was quantification of the risk. The authors found that only the board size was related negatively and significantly to the voluntary risk disclosure. Based on 90 Dutch listed firms, Deumes (2008) investigated whether companies report risk-relevant information to potential investors for the period from 1997 to 2000. The author grouped the risk information under eight categories including "macro environmental sources, industry sources, internal sources, other sources, loss and probability of loss, variance, lack of information and lack of control". Results indicated that the risk information predicted the volatility of companies' future stock prices.

In respect to some Asian countries, Probohudono, Tower and Rusmin (2013) performed a study to identify the level and determinants of risk disclosure among 60 manufacturing companies from four countries including Indonesia, Malaysia, Singapore, and Australia during the global financial crisis (2007-2009). Results indicated that the average disclosure level was only $28.61 \%$. Ali and Taylor (2014) grouped the risk information of Malaysian listed companies for 2009 in four categories including "operational risk, environmental risk, financial and strategic risk". The authors found that financial risks and operational risks were the main disclosed risks in annual corporate reports, while the least disclosed risks were the strategic and environmental ones. The authors found that the infrastructure and technology industry was the first in the disclosure level. Dey, Hossain and Rezae (2018) developed a financial risk disclosure index using a content analysis based on 30 indicators grouped under 6 categories including "liquidity risk, credit risk, interest rate risk, currency risk, capital structure risk, and general" to test the relationship between the internal characteristics of 48 manufacturing listed Bangladeshi companies for the period from 2010 to 2015 and the level of financial risk disclosure. Results indicated that the average level of financial risk disclosure was 0.44 as an average financial risk disclosure level for the period and that the level of disclosure was positively and significantly associated with size, financial performance, and auditor type, while the other variables (leverage, liquidity, and industry type) not related to the level of financial risk disclosure.

In respect to Arab countries, Hassan (2009) developed un-weighted risk disclosure index including 45 items based on standards, prior accounting literature and UAE regulatory requirements distributed over seven categories including "general risk information, accounting policies, financial instruments, derivative hedging, reserves, segment information and financial, and other risks". The findings indicated that the mean of corporate disclosure index of the 41 UAE companies was 19.6098. Hemrit and Ben Arab (2011) performed a study to investigate the determinants and the disclosure practices of operational risk over four categories including "definition, operational risk, regulatory issues and operational risk events" in 14 Tunisian insurance companies during the period from 2000 to 2009 . The authors' findings indicated that the disclosure score was increased significantly from 64 points in 2000 to 158 points in 2009 and it was linked to size of firm, the intensity of provisions and leverage. Using a manual content analysis, 
Al-Shammari (2014) performed a study to investigate the relationship between corporate internal characteristics (i.e. company size, leverage, liquidity, profitability, complexity, auditor type, and industry type) and the level of risk disclosure. The author develop seven categories of risk disclosure including "general risk information, accounting policies, financial instruments, derivative hedging, reserves, segment information with financial and other risks and commodity risk" for 109 non-financial listed Kuwaiti companies for 2012. The results indicated that the mean of disclosed sentences of risk disclosure was 19.87 and most frequently disclosed categories were financial and reserves risks, while the lowest category was commodity risk. Findings also revealed that the level of risk disclosure related to size, liquidity, complexity and auditor type. Ellili and Nobanee (2017) used a risk disclosure index over five categories including "strategic, operational, financial, damage and risk management" to measure the level of risk disclosure among the UAE banks for the period from 2003 to 2013. The authors' findings indicated that the level of risk disclosure was on average $35 \%$ for all banks.

In context of Jordan, very limited studies were performed to investigate the risk disclosure. In this context and based on the requirements of IFRS 7 and the prior research in the field, Alkurdi et al. (2019) developed a risk disclosure index including both the voluntary and mandatory items over three categories including "credit; market; and liquidity risk" to test its impact on corporate governance mechanisms among 15 Jordanian banks during the period from 2008 to 2015 . The results indicated that mandatory risk disclosure reached 0.94 with a mean of 0.85 , while the voluntary risk disclosure reached 0.80 with a mean of 0.57 . Other studies focused on the disclosure in general such as that of Suwaidan, Al-Omari and Haddad (2004) who performed a study to identify the level and determinants of social responsibility disclosure practices among 65 industrial Jordanian companies through developing a disclosure index. Results show a low level of disclosure on a total average of $13 \%$ and that profit, risk and size were the main determinants of social responsibility disclosure level. Omar and Simon (2011) strived to determine the disclosure practices and their determinants among 121 industrial and services Jordanian listed companies for 2003. The authors developed a disclosure index including 331 voluntary and mandatory disclosure items along nine categories. Results revealed that on average the total disclosure level was $69.3 \%$, the mandatory disclosure level was $83.12 \%$, while the voluntary one was only $34.51 \%$. AlZubi and Al-Zubi (2013) performed a survey to determine the level and quality of disclosure in the time of financial crisis based on the responses from both the investors and academics. Authors' findings revealed that there was a disagreement between respondents in their view to disclosure quantity. Mardini, Tahat and Power (2013) performed a study to determine the factors that affect the segmental disclosure level for 2009. Authors' findings indicated that profit, size and audit firm are significantly affected the segmental disclosure level. Haddad, Sbeiti and Qasim (2017) performed a study to determine the change in the disclosure level among Jordanian companies over the period from 1986 to 2014 and the contextual variable that affected such level based on the results of prior Jordanian studies that conducted in this regard. Results of the study revealed that the quantity of disclosure is enhanced over time and that the size, trading agreements, economic reform policy, and the related legislative laws contributed in such enhancement.

\section{Methodology}

\subsection{Data and Sample}

The objectives of the current study are based mainly on the request of JSC from Jordanian listed companies to send disclosure reports explain the effect of the COVID-19 pandemic on their activities in terms of material information, operational activities and the decisions of board of directors during the period of disclosure suspension extending from March 18, 2020 to May 5, 2020. Accordingly, the listed companies were sent the required reports and are now available for users on the website of ASE. Therefore, the researcher downloaded all these reports by entering the symbol of each company at the GET QUOTES box that available on the website of ASE. (Note 1) This gave the opportunity to show all the disclosures of a listed company. The researcher then investigated the contents of reports one by one manually (Al-Shammari, 2014) to determine the pattern of disclosures that these companies focused on during the reporting period that was given by JSC. It was common in corporate reporting studies to depend on resources other than annual reports (e.g. Oliveira, Rodrigues \& Craig, 2006). In this regard, prior researchers critiqued the reliance only on annual corporate reports in investigating risk information and stressed the importance of using other sources (Oliveira, Rodrigues \& Craig, 2013; Al-Shammari, 2014). Accordingly, the current study did not depend on annual corporate reports to extract the risk disclosure items; instead it depended on separate disclosure reports sent to JSC by Jordanian listed companies during May, 2020. The disclosure reports were in Arabic language and the required contents were directly translated to English language by the author.

Jordan has four main sectors including banking, insurance, services and industry. The data necessary to achieve the objectives of the study were obtained from disclosure reports of services and industrial nonfinancial companies listed 
at the first market. Therefore, the current study depends on two sectors including services and industry. The total listed and traded companies at the first and second market as of June 3, 2020 are 185 companies. (Note 2) 68 financial companies were excluded and 85 companies that traded in the second market were also excluded. Accordingly, the final sample includes 32 companies as shown in Table 2, with 20 services listed companies and 12 industrial listed companies. The justification for excluding the financial companies is due to the great variation in the nature of their operational activities from those of other companies, which may distort the results of the study. In addition, the financial companies tend to disclose more risk information due to the requirements of several regulatory authorities (Madrigal et al., 2015). However, the study is limited to an effective group of services and industrial non-financial companies listed on the ASE (Marzouk, 2016) and the sample size of the study exceeds that of several risk disclosure studies (e.g. Hemrit \& Ben Arab, 2011; Höring \& Gründl, 2011; Ismail, Rahman \& Ahmad, 2013; Marzouk, 2016) and other corporate reporting studies (Abeysekera \& Guthrie, 2005). In addition, the study sample includes all the non-financial industrial and services companies listed on the first market of ASE.

Consistent with Marzouk (2016) work, the current study was conducted during the crisis period, and therefore represents an important addition to the corporate reporting studies. In addition, the current study is exploratory in nature and tries to offer the model of risk disclosure that Jordanian nonfinancial listed companies followed while they were in critical circumstances. Therefore, the current study offers something new. However, the researcher investigated the following resources while looking for the risk items:

1. Article (8) and article (9) of Instructions of Issuing Companies Disclosure, Accounting and Auditing Standards for the Year 2004. These two articles include the mandatory disclosure requirements in Jordan.

2. IFRS 7. Jordanian companies are obligated to implement international financial reporting standards (IAS/IFRS) by law. IFRS 7 gives in some details all the necessary information about the risk disclosure.

3. Jordanian Companies Law No. (22) of 1997 and the Securities Law of 2002.

4. The prior studies in the field of risk disclosure which include a broad set of voluntary risk items over several categories (e.g. Lajili \& Zéghal, 2005; Deumes, 2008; Hassan, 2009; Ali \& Taylor, 2014; Al-Shammari, 2014; Marzouk, 2016; Ellili \& Nobanee, 2017).

However, considerable efforts have been made to extract all risk disclosure items that reported in the disclosure reports required by JSC. Consistent with prior research in the field (e.g. Ali \& Taylor, 2014; Al-Shammari, 2014; Marzouk, 2016) a sentence approach was used to extract the risk disclosure as it more precise than the word or other approaches (Marzouk, 2016). The item was approved if it was related to the actual events occurred during the COVID-19 pandemic or expected to occur in the future as a result of the pandemic (e.g. Marzouk, 2016) and was approved even if only one company disclosed it. For example, if a company mentions that it suffers from the inability to collect certain fees from customers due to the COVID-19 pandemic, this means that it has risks related to cash flow and liquidity risk item. After that, any company that disclosed similar information was added to the list.

Table 2. The study sample

\begin{tabular}{ll}
\hline Description & Number of companies \\
\hline Listed and traded on the first and second market & 185 \\
Financial & $(68)$ \\
Listed on the second market & $(85)$ \\
Final sample & $\underline{\mathbf{3 2}}$ Companies distributed as follows: \\
Educational Services & 5 \\
Hotel and Tourism & 3 \\
Transportation & 1 \\
Technology and Communication & 4 \\
Utilities and Energy & 2 \\
Commercial Services & 2 \\
Pharmaceutical and Medical industries & 1 \\
Chemical Industries & 2 \\
Food and Beverages & 1 \\
Tobacco and Cigarettes & 3 \\
Mining and Extraction industries & 2 \\
Engineering and Construction & 1 \\
Textile, Leather and Clothing &
\end{tabular}




\section{Results and Discussion}

\subsection{Response to the Disclosure Requirements of JSC}

It has been argued that improvement in the legislative environment in Jordan is the major reason for the improvement of disclosure level among Jordanian companies (Omar \& Simon, 2011). Accordingly, JSC asked the listed companies to send disclosure reports include the effect of the COVID-19 pandemic on their activities in terms of material events, operational activities and the decisions of board of directors during the period of disclosure suspension extending from March 18, 2020 to May 5, 2020. Accordingly, the entire study sample (32) sent the disclosure report to JSC. The next sections show the extent of response to the three requests.

\subsubsection{Material Information and Events}

Table (3) offers the response of the study sample to the first point of JSC which asked about the material events. It looks that $43.8 \%$ of the study sample mentioned in their disclosure report that there are material events or information, while $40.6 \%$ mentioned that there are no material events. This means that the total percentage of response to the material event point is about $84.4 \%$. Even in the absence of material events, JSC asked companies to mention that there are no material events during the required period (JSC, 2020). Despite that, the percentage of nonresponse is $15.6 \%$ of the study sample. This may be justified based on the notion that such companies may try to hide some information as such information according to the theory of proprietary may be exploited by competitors in the market (Lajili \& Zéghal, 2005; Domínguez \& Gámez, 2014; Mokhtar, Elharidy \& Mandour, 2018). Notably that Article (8) of Instructions of Issuing Companies Disclosure, Accounting and Auditing Standards for the Year 2004 requires a full disclosure about such events.

Table 3. The extent of response to the disclosure of material events

\begin{tabular}{lll}
\hline Material information disclosure & No. of Companies & $\%$ \\
\hline Companies mentioned that there are material events in the disclosure report & 14 & $43.8 \%$ \\
Companies mentioned that there are no material events in the disclosure report & 13 & $40.6 \%$ \\
Companies mentioned nothing about the material events in the disclosure report & 5 & $15.6 \%$ \\
Total & 32 & $100 \%$ \\
\hline
\end{tabular}

5.1.2 Activities and Business Operations

In respect to the activities and business operations, Table (4) shows that the entire study sample (100\%) disclosed such information. This, however, is normal as such information is related mainly to the daily operations of each company and cannot be hidden, especially since most companies in Jordan have stopped their activities based on the defense ordinance No. 2. This is because each company has its own suppliers and customers who also affected by the COVID-19 pandemic, either by preventing of movement or closures that took place on different crossings and borders.

Table 4. The extent of response to the disclosure of activities and business operations

\begin{tabular}{lll}
\hline Business operations disclosure & No. of Companies & $\%$ \\
\hline $\begin{array}{l}\text { Companies that reported the effect on the activities and business operations in the } \\
\text { disclosure report }\end{array}$ & 32 & $100 \%$ \\
Total & 32 & $100 \%$ \\
\hline
\end{tabular}

5.1.3 Board of Directors' Decisions

The third point that JSC asked the listed companies to disclose was any significant decisions that have been taken by board of directors during the disclosure suspension period, especially those related to dividends. In this respect, the defense ordinance No. 5 suspended the procedures of companies law No. 22 for 1997 in respect to the meetings of general assembly and board of directors of listed companies as of March 18, 2020 and gave the Minister of Industry, Trade and Supply the right to issue the necessary instructions to arrange such meetings. On April 9, 2020 the Minister of Industry, Trade and Supply identified the holding of such meetings through visual and electronic means. Table 5 shows the extent of response to the disclosure of board of directors meetings. The results show that $87.5 \%$ of the study sample did disclose something about the decisions and meetings of board of directors whether the meetings held or not. For example, some companies mentioned that the board of director "not held" (50\%), others (25\%) mentioned another sentence "no decisions" as shown in Table (6) below. 
Table 5. The extent of response to the disclosure of board of directors meetings

\begin{tabular}{|c|c|c|c|c|}
\hline \multicolumn{3}{|c|}{ Board of directors' decisions } & No. of Companies & $\%$ \\
\hline \multicolumn{3}{|c|}{$\begin{array}{l}\text { Companies that disclose any information about the decisions and meetings of } \\
\text { board of directors in the disclosure reports whether the meetings were held or } \\
\text { not. }\end{array}$} & 28 & $87.5 \%$ \\
\hline \multicolumn{3}{|c|}{$\begin{array}{l}\text { Companies mentioned nothing about meetings or decisions of board of directors } \\
\text { in the disclosure reports. }\end{array}$} & 4 & $12.5 \%$ \\
\hline \multicolumn{3}{|l|}{ Total } & 32 & $100 \%$ \\
\hline \multicolumn{5}{|c|}{ Table 6. The nature of disclosure } \\
\hline Nature of disclosure & No. of companies & $\%$ & & \\
\hline Held & 7 & $25 \%$ & & \\
\hline Not held & 14 & $50 \%$ & & \\
\hline No decisions & 7 & $25 \%$ & & \\
\hline Total & 28 & $100 \%$ & & \\
\hline
\end{tabular}

\subsection{Risk Disclosure Pattern}

\subsubsection{Extraction of Risk Items}

As shown in Table 7, 20 risk items were extracted from the 32 disclosure reports. The researcher relied on previous studies (Lajili \& Zéghal, 2005; Linsley \& Shrives, 2006; Deumes, 2008; Hassan 2009; Ali \& Taylor, 2014; Al-Shammari, 2014; Marzouk, 2016) to name 11 items, while the others were named by the author using the common accounting terms. The extracted risk items are diverse and represent an important addition to the knowledge in this field.

Table 7. Risk items extracted from the disclosure reports that sent to JSC

\begin{tabular}{lll}
\hline No & Risk disclosure item & Source of the item name \\
\hline 1 & Cash flow and liquidity risk & Ali and Taylor (2014); Al-Shammari (2014) \\
2 & Paying or bearing operating or capital costs & Author \\
3 & Receivable collection risks & Author \\
4 & Loss and probability of loss & Deumes (2008) \\
5 & Exchange rate risk & Hassan (2009); Al-Shammari (2014) \\
6 & Contingent liabilities and obligations & Al-Shammari (2014);Hassan (2009) \\
7 & Activities and business operations risks & Hassan (2009) \\
8 & Interruptions in the delivery chain & Linsley and Shrives (2006) \\
9 & Price fluctuations of the factors of production & Linsley and Shrives (2006) \\
10 & Production reduction & Author \\
11 & A decrease in the sales & Author \\
12 & Competition risks & Lajili and Zéghal (2005) \\
13 & Loss of customers & Lajili and Zéghal (2005) \\
14 & Supply of goods and raw materials risks & Ali and Taylor (2014) \\
15 & Dividend risks & Hassan (2009) \\
16 & Risks of not holding the general assembly meetings & Author \\
17 & Risks of not taking decisions by boards & Author \\
18 & Risks of not holding the board of directors meetings & Author \\
19 & The image is unclear for the future & Author \\
20 & The risks of continuing the pandemic on different activities & Author \\
\hline & & \\
\hline
\end{tabular}




\subsubsection{Categories of Risk Disclosure}

According to Deumes (2008) one of the procedures of content analysis is to develop relevant categories of risk disclosure and then to distribute the risk items to the relevant categories. In respect to the current study, very precise procedures used to distribute the extracted items to the relevant categories. Accordingly, the 20 risk items distributed over five categories as shown in Table 8 . The number of the categories in the current study exceeds that of several prior studies as Hemrit and Ben Arab (2011) and Ali and Taylor (2014). These categories include: financial risks, operational risks, market risks, investor relation risks and strategic risks. The researcher investigated the risk categories used in prior studies (Lajili \& Zéghal, 2005; Deumes, 2008; Hassan, 2009; Hemrit \& Ben Arab, 2011; Höring \& Gründl, 2011; Ali \& Taylor, 2014; Al-Shammari, 2014; Domínguez \& Gámez, 2014; Madrigal et al., 2015; Marzouk, 2016, Ellili \& Nobanee, 2017; Dey, Hossain \& Rezae, 2018; Alkurdi et al., 2019) and tested the disclosure practices as outlined in Omar and Simon (2011) in order to develop the current disclosure categories. The financial, operational and even the strategic category are common in risk disclosure literature such as Ali and Taylor (2014), while the market (Lajili \& Zéghal, 2005; Ali and Taylor, 2014) and investor relation (Deumes, 2008; Hassan, 2012) categories are very limited in prior studies. Therefore, one of the main contributions of the current study is that it offers a new disclosure risk model includes 20 items distributed over five categories (Hemrit \& Ben Arab, 2011; Dey, Hossain \& Rezae, 2018). These categories should be given more emphasis during crisis periods. In addition, there is a variety in the extracted items (Sundmacher \& Ford, 2006), which enriches the study and helps the potential researchers to start new studies in the effect of the COVID-19 pandemic on various aspects of accounting reporting practices. Moreover, the five categories are comprehensive as they consistent with the definition of corporate risk disclosure as suggested by Hassan (2009). In general, the results show that the financial risks are the most numerous (6 items) followed by operational risks (5 items). These results are consistent with those of Ali and Taylor (2014), who found that operational and financial risk categories are contained the largest number of risk sentences.

Table 8. Distribution of the extracted risk items over the relevant categories

\begin{tabular}{|c|c|c|}
\hline $\begin{array}{lll}\begin{array}{l}\text { Category } \\
\text { disclosure }\end{array} & \text { of } & \text { risk } \\
\end{array}$ & $\begin{array}{l}\text { No. of } \\
\text { items }\end{array}$ & Risk disclosure items \\
\hline & 1. & Cash flow and liquidity risk \\
\hline & 2. & Paying or bearing operating or capital costs \\
\hline \multirow[t]{6}{*}{ Financial risks } & 3. & Receivable collection risks \\
\hline & 4. & Loss and probability of loss \\
\hline & 5. & Exchange rate risk \\
\hline & 6. & Contingent liabilities and obligations \\
\hline & 1. & Activities and business operations risks \\
\hline & 2. & Interruptions in the delivery chain \\
\hline \multirow[t]{4}{*}{ Operational risks } & 3. & Price fluctuations of the factors of production \\
\hline & 4. & Production reduction \\
\hline & 5. & A decrease in the sales \\
\hline & 1. & Competition risks \\
\hline \multirow[t]{3}{*}{ Market risks } & 2. & Loss of customers \\
\hline & 3. & Supply of goods and raw materials risks \\
\hline & 1. & Dividend risks \\
\hline \multirow[t]{4}{*}{ Investor relation risks } & 2. & Risks of not holding the general assembly meetings \\
\hline & 3. & Risks of not taking decisions by boards \\
\hline & 4. & Risks of not holding the board of directors meetings \\
\hline & 1 & The image is unclear for the future \\
\hline Strategic risks & 2 & The risks of continuing the pandemic on different activities \\
\hline Total & 20 & \\
\hline
\end{tabular}




\subsubsection{Extent of Risk Items Disclosure}

Table 9 shows the extent of disclosure of each item by different companies. The 32 disclosure reports were tested and any sentence containing or including any reference to risk of any kind has been taken into consideration and then has been extracted and installed even if only one company has disclosed it. Since the current study is exploratory in nature and seeks to identify all the items of risk that disclosed by companies, it looks that some items do not have a large consensus from all companies. The inconsistency in disclosure among companies can be returned to several reasons, including the sudden cessation of work and the presence of other influencing factors that differ from one company to another, such as the nature of the work, the ability to follow up the work remotely, and the extent of reliance on other parties and markets.

However, the results show that three items (i.e. exchange rate risk, price fluctuations of the factors of production and competition risks) were disclosed by only one company for each of them. On the other hand, the entire study sample disclosed information about operational risks. In addition, 17 companies disclosed that they paid or bear costs during the suspension period. This followed by a decrease in the sales as 14 companies reported that. The cash flow and liquidity risk and dividend risks ranked fourth with a disclosure rate of $37.5 \%$. Most important, $34.4 \%$ of the study sample disclosed that the future is in general characterized by uncertainty, as they have no idea about the expected time span for the pandemic to continue. Moreover, Jordanian companies expressed their concern about the contingent liabilities and obligation at a percentage of $28.1 \%$. In addition, suspending the meetings of general assembly and board of directors had their share in the disclosures.

Table 9. The extent of disclosure of each risk's item

Disclosure item

$\begin{array}{ll}\begin{array}{l}\text { No. of companies } \\ \text { disclosed the item }\end{array} & \begin{array}{l}\text { Extent of } \\ \text { disclosure }\end{array}\end{array}$

\section{Financial Risks}

Paying or bearing operating or capital costs

Cash flow and liquidity risk

Receivable collection risks

Contingent liabilities and obligations

Loss and probability of loss

Exchange rate risk

Operational risks

Activities and business operations risks

A decrease in the sales

Interruptions in the delivery chain

Production reduction

Price fluctuations of the factors of production

\section{Market risks}

Loss of customers

Supply of goods and raw materials risks

Competition risks

\section{Investor relation risks}

Dividend risks

Risks of not holding the general assembly meetings

Risks of not taking decisions by boards

Risks of not holding the board of directors meetings

\section{Strategic risks}

The image is unclear for the future

The risks of continuing the pandemic on different activities 
Based on the number of disclosed companies, Table 10 shows the extent of disclosure of each category and the total average of disclosure of all categories by the different companies. In particular, the total average of disclosure is 65.6\%. This level of disclosure is less than that of Lajili and Zéghal (2005) and Höring and Gründl (2011) and exceeds that of Ellili and Nobanee (2017) and Dey, Hossain and Rezae (2018). It looks that 24 companies of 32 disclosed information related to financial risk category at a percentage of $75 \%$. For example, the chemical industry disclosed nothing about the financial risk category, while all the educational companies (5) disclosed financial risks. In addition, it looks that the entire study sample (32) disclosed operational risks (OR). This followed by investor relation risk category (IRR) (78.1\%), financial risk category (FR) (75\%), strategic risk category (SR) (46.9\%), and finally the market risk category which ranked last at a disclosure rate of $28.1 \%$ only.

1. Operational risks category (OR): as mentioned above, OR was resulted from the suspension of operations of different sectors in Jordan. In addition, JSC in its letter to listed companies asked them in point 2 to send an initial report about the impact of the COVID-19 pandemic on their activities and operational business. Therefore, it is normally for operational risks to be disclosed by all companies.

2. Investor relation risks category (IRR): IRR category ranked second as 25 companies of 32 companies disclosed the information that related to the suspension of the board of directors and general assembly meetings. In addition, the investor relation category includes the dividend policy during the COVID-19 pandemic. In this regard, it is useful to clarify that some of the companies had been recommended paying dividends before the crisis, but with the COVID-19 pandemic, some companies have canceled the decision of payment, while others have reduced the dividend ratio. Furthermore, the failure to hold meetings on time has deferred the decisions of dividends, delayed the payment of dividends, delayed the approval of financial statements and affected negatively several activities in such companies. The disclosure level $(78.1 \%)$ of IRR is considered satisfactory and gives a good indicator about the behavior of management in reporting information necessary to the current and potential investors (Deumes, 2008).

3. Financial risks category $(\boldsymbol{F R})$ : FR category ranked third with a percentage of $75 \%$. The FR includes the largest number of items among all categories and most of such items indicated that some companies have influenced directly during the period of suspension. For example, the suspension period impacted negatively the cash flows and liquidity in several companies as a result of the decrease in sales and the inability of companies to collect their receivables while still incurring some expenses such as salaries. The importance of financial risk category comes from the importance of its indicators and the emphasis of IFRS 7 on some of such indicators like liquidity.

4. Strategic risks category (SR): SR category ranked fourth and focused on the inability of some companies to predict the future and their fear that the COVID-19 pandemic will continue for long periods of time, which deepens its negative impact.

5. Market risks category (MR): MR category came the last with a percentage of $28.1 \%$. These risks were resulted mainly from fearing of some companies to lose their usual customers and markets. This fear is normal, as the pandemic affected even the consumption behavior of some people. The lower number of companies that reported in this category was resulted from the absence of the normal conditions of competition in the light of current crisis and as most companies were interested mainly in keeping their presence in the market.

The rows in Table 10 also show the average of disclosure by each industry. For example, the sample of the study includes five educational companies. All of them (100\%) disclosed information in FR category and OR category, while only 1 company (20\%) disclosed information in MR category, 4 companies (80\%) disclosed information in IRR category and 2 companies (40\%) disclosed information in SR category. In particular, Table 10 shows that Tobacco and Cigarettes industry comes first (100\%) as it was disclosed information in all categories. This followed by three industries including Technology and communication, Pharmaceutical and Medical and Textile, Leather and Clothing at a percentage of $80 \%$ for each of them. This result is almost consistent with that of Ali and Taylor (2014) who found that the infrastructure and technology industry was the first in the disclosure level. Mining and Extraction industry came third at a percentage of $73.3 \%$ followed by Hotel and Tourism at a percentage of $72 \%$ and educational companies at a percentage of $68 \%$. Three industries including Utilities and Energy, Commercial Services and Engineering and Construction came sixth at a percentage of $60 \%$ for each of them followed by transportation industry at a percentage of 53.3\%. Finally, both Chemical and Food and Beverages industries came last at a percentage of $40 \%$ for each of them. It has been noticed through the disclosure reports and the current results that those companies that were suspended completely during the COVID-19 pandemic such as Tobacco and Cigarettes companies were severely affected, thus reported risk disclosures in all categories, while those vital companies that were excluded from the suspension of work wholly or partially were little affected, thus their disclosures were less such as chemical and food companies. 
Table 10. Extent of risk disclosure of each category by industries

\begin{tabular}{|c|c|c|c|c|c|c|c|c|c|c|c|c|c|}
\hline \multirow{2}{*}{\multicolumn{2}{|c|}{ Industry }} & \multicolumn{12}{|c|}{ Number of Companies $\mathrm{N}=32$} \\
\hline & & $\underline{N}$ & $\underline{F R}$ & $\%$ & $\underline{O R}$ & $\underline{\%}$ & $\underline{M R}$ & $\underline{\%}$ & $\underline{I R R}$ & $\underline{\boldsymbol{q}}$ & $\underline{S R}$ & $\underline{\%}$ & Average \\
\hline Educational Services & & 5 & 5 & $100 \%$ & 5 & $100 \%$ & 1 & $20 \%$ & 4 & $80 \%$ & 2 & $40 \%$ & $68 \%$ \\
\hline Hotel \& Tourism & & 5 & 3 & $60 \%$ & 5 & $100 \%$ & 2 & $40 \%$ & 5 & $100 \%$ & 3 & $60 \%$ & $72 \%$ \\
\hline Transportation & & 3 & 1 & $33.3 \%$ & 3 & $100 \%$ & 0 & $0 \%$ & 3 & $100 \%$ & 1 & $33.3 \%$ & $53.3 \%$ \\
\hline Tech \& communicati & & 1 & 1 & $100 \%$ & 1 & $100 \%$ & 0 & $0 \%$ & 1 & $100 \%$ & 1 & $100 \%$ & $80 \%$ \\
\hline Utilities \& Energy & & 4 & 4 & $100 \%$ & 4 & $100 \%$ & 0 & $0 \%$ & 3 & $75 \%$ & 1 & $25 \%$ & $60 \%$ \\
\hline Commercial Services & & 2 & 1 & $50 \%$ & 2 & $100 \%$ & 0 & $0 \%$ & 2 & $100 \%$ & 1 & $50 \%$ & $60 \%$ \\
\hline $\begin{array}{l}\text { Pharmaceutical } \\
\text { Medical }\end{array}$ & $\&$ & 2 & 2 & $100 \%$ & 2 & $100 \%$ & 2 & $100 \%$ & 1 & $50 \%$ & 1 & $50 \%$ & $80 \%$ \\
\hline Chemical Industries & & 1 & 0 & $0 \%$ & 1 & $100 \%$ & 1 & $100 \%$ & 0 & $0 \%$ & 0 & $0 \%$ & $40 \%$ \\
\hline Food \& Beverages & & 2 & 1 & $50 \%$ & 2 & $100 \%$ & 0 & $0 \%$ & 1 & $50 \%$ & 0 & $0 \%$ & $40 \%$ \\
\hline Tobacco \& Cigarettes & & 1 & 1 & $100 \%$ & 1 & $100 \%$ & 1 & $100 \%$ & 1 & $100 \%$ & 1 & $100 \%$ & $100 \%$ \\
\hline Mining \& Extraction & & 3 & 3 & $100 \%$ & 3 & $100 \%$ & 1 & $33 \%$ & 2 & $66,7 \%$ & 2 & $66.7 \%$ & $73.3 \%$ \\
\hline $\begin{array}{l}\text { Engineering } \\
\text { Construction }\end{array}$ & $\&$ & 2 & 1 & $50 \%$ & 2 & $100 \%$ & 1 & $50 \%$ & 1 & $50 \%$ & 1 & $50 \%$ & $60 \%$ \\
\hline $\begin{array}{l}\text { Textile, Leather } \\
\text { Clothing }\end{array}$ & $\&$ & 1 & 1 & $100 \%$ & 1 & $100 \%$ & 0 & $0 \%$ & 1 & $100 \%$ & 1 & $100 \%$ & $80 \%$ \\
\hline Total & & 32 & 24 & $75 \%$ & 32 & $100 \%$ & 9 & $28.1 \%$ & 25 & $78.1 \%$ & 15 & $46.9 \%$ & $65.6 \%$ \\
\hline
\end{tabular}

Consistent with the work of Rashid et al. (2012), Table 11 gives a summary to the most and the least disclosed items according to categories. It starts with the most disclosed category (Operational), then the row includes the first three disclosed items and the least disclosed item of each category.

Table 11. Summary of the risk disclosure pattern

\begin{tabular}{|c|c|c|c|c|}
\hline Category & Most disclosed & $2^{\text {nd }}$ disclosed & $3^{\text {rd }}$ disclosed & Least disclosed \\
\hline \multirow[t]{2}{*}{ Operational } & \multirow[t]{2}{*}{$\begin{array}{l}\text { Activities and business } \\
\text { operations risks }\end{array}$} & \multirow[t]{2}{*}{$\begin{array}{l}\text { A decrease in the } \\
\text { sales }\end{array}$} & $\begin{array}{l}\text { Interruptions in the delivery } \\
\text { chain }\end{array}$ & \multirow[t]{2}{*}{$\begin{array}{l}\text { Price fluctuations of the } \\
\text { factors of production }\end{array}$} \\
\hline & & & Production reduction & \\
\hline $\begin{array}{l}\text { Investment } \\
\text { relation }\end{array}$ & Dividend risks & $\begin{array}{l}\text { Risks of not } \\
\text { holding the } \\
\text { general assembly } \\
\text { meetings }\end{array}$ & $\begin{array}{l}\text { Risks of not taking decisions by } \\
\text { boards }\end{array}$ & $\begin{array}{l}\text { Risks of not holding the } \\
\text { board of directors } \\
\text { meetings }\end{array}$ \\
\hline \multirow[t]{2}{*}{ Financial } & \multirow{2}{*}{ 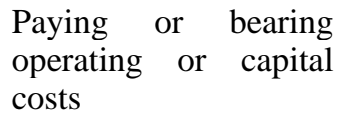 } & \multirow{2}{*}{$\begin{array}{l}\text { Cash flow and } \\
\text { liquidity risk }\end{array}$} & Receivable collection risks & \multirow[t]{2}{*}{ Exchange rate risk } \\
\hline & & & $\begin{array}{l}\text { Contingent liabilities } \\
\text { obligations }\end{array}$ & \\
\hline Strategic & $\begin{array}{l}\text { The image is unclear } \\
\text { for the future }\end{array}$ & & & $\begin{array}{l}\text { The risks of continuing } \\
\text { the pandemic on } \\
\text { different activities }\end{array}$ \\
\hline Market & Loss of customers & $\begin{array}{l}\text { Summary of the } \\
\text { risk disclosure } \\
\text { pattern }\end{array}$ & & Competition risks \\
\hline
\end{tabular}




\subsubsection{Types of Disclosed Risk Information}

Usually the risk information can be expressed financially (quantitatively) or non-financially (qualitatively) (Hassan, 2009). In this context, IFRS 7 requires companies to disclose both the quantitative and qualitative information (Höring \& Gründl, 2011) and is put more emphasis on disclosing the information quantitatively. Therefore, by investigating the disclosure reports of the sample during the suspension period, it was found that some companies offered some of the effect of the COVID-19 pandemic quantitatively. Table 12 shows the types of risk information disclosed. It has been found that about $43.8 \%$ of the study sample offered the risk information quantitatively in their disclosure reports that sent to JSC. Such quantitative information includes for example the decline amount or percentage of the sales or earnings during the required period. However, it is expected that the quantitative information about the effect of the COVID-19 pandemic on the Jordanian listed companies will be reported in details at the annual corporate reports of 2020. However, the entire study sample (100\%) disclosed qualitative information. This result is consistent with that of prior risk disclosure studies (Lajili \& Zéghal, 2005; Ali \& Taylor, 2014) and other corporate reporting studies (Oliveira, Rodrigues \& Craig, 2006) where the majority of disclosed information was qualitative. The smaller number of companies that disclosed quantitatively was due to the uncertainty that these companies were experienced during the Corona pandemic.

Table 12. Types of disclosed risks

\begin{tabular}{lll}
\hline Disclosure type & No. of Companies & $\%$ \\
\hline Quantitative & 14 & $43.8 \%$ \\
Qualitative & 32 & $100 \%$ \\
\hline
\end{tabular}

\section{Conclusion and Recommendation}

This study comes at a critical time to determine the risk disclosure pattern of Jordanian companies during the COVID-19 pandemic in response to the request of JSC. In particular, JSC asked all Jordanian listed companies to prepare and send disclosure reports include the effect of the COVID-19 pandemic on their activities in terms of material events, operational activities and the decisions of board of directors during the period of disclosure suspension extending from March 18, 2020 to May 5, 2020. The request of JSC based on Article (8) of the Instructions of Issuing Companies Disclosure, Accounting and Auditing Standards for the Year 2004. Accordingly, the disclosure reports were sent and were listed for users on the website of ASE. All the non-financial companies that listed on the first market were chosen to carry out this study. Therefore, the results of the current study based on the 32 industrial and services companies listed on the ASE. To extract all the risk items, the related Jordanian legislations, IFRS 7 and prior studies in risk disclosure and corporate reporting were investigated. Accordingly, all the disclosure reports were downloaded and the content of each report was manually investigated.

The results of this study are numerous. In respect to the response to the request of JSC, results show that the entire study sample (100\%) did send the disclosure reports to JSC and presented the necessary information about the effect of the COVID-19 pandemic on their activities in terms of material events, operational activities and the decisions of board of directors during the disclosure suspension period.

In terms of the quality of disclosed risks, extraction process resulted in 20 risk items distributed over five categories including financial risks, operational risks, market risks, investor relation risks and strategic risks. These categories include a wide variety of important risk items such as cash flow and liquidity risk, costs, receivables, losses, and contingent liabilities in financial category. Business operations risks, deliver chain risks, price fluctuations, production and sales risks are related to operational risk category. The other three categories (i.e. market, investor relations and strategic) include important risk items and are considered an important addition to the prior studies in risk disclosure. For example, the market category includes competition risks, loss of customers and supply of goods and raw materials risks, while the investment relation category includes dividend risks, risks of not holding general assembly and board meetings. Finally, the strategic category includes two items focusing on the risks of uncertainty and the risks of pandemic continuity. In addition to the qualitative information, about $43.8 \%$ of the study sample disclosed quantitative information. However, such information will be mentioned again in more details at the 2020 annual corporate reports as reported by some companies.

In respect to the extent of disclosure and since the current study is an exploratory in nature, there is no prior disclosure model to compare with and to determine the extent of disclosure of each item. For example, the current study includes unique items not used before such as those of investor relation category. Therefore, the quantity of disclosure depends mainly on the number of disclosers of each category. The results show that the average disclosure 
level is $65.6 \%$. The operational category ranked first as $100 \%$ of the study sample disclosed operational information. This followed by investor relation category $(78.1 \%)$, financial category (75\%), strategic category (46.9\%) and finally the market category came last as only $28.1 \%$ of the study sample disclosed information on it. In respect to the items, results show that activities and business operations risks came first as $100 \%$ of the study sample disclosed information about such risks. This followed by paying or bearing operating or capital costs as 17 companies of 32 disclosed information on such risks at a percentage of (53.1\%). A decrease in the sales came third at a percentage of $43.8 \%$, while cash flow and liquidity risk came fourth at a percentage of $37.5 \%$. $34.4 \%$ of the study sample expressed their fear regarding the future and came fifth. These five items represent the direct effect of the COVID-19 pandemic.

In respect to the level of disclosure according to industries, results revealed that Tobacco and Cigarettes industry came first $(100 \%)$ as it disclosed information in all categories. This followed by three industries including Technology and Communication, Pharmaceutical and Medical and Textile, Leather and Clothing industry at a percentage of $80 \%$ for each of them. Mining and Extraction industry came third at a percentage of $73.3 \%$ followed by Hotel and Tourism industry at a percentage of $72 \%$ and educational industry at a percentage of $68 \%$. Three industries including Utilities and Energy, Commercial Services and Engineering and Construction came sixth at a percentage of $60 \%$ for each of them. This followed by transportation industry at a percentage of $53.3 \%$. Finally, both Chemical and Food and Beverages industries came last at a percentage of $40 \%$ for both of them. Most important, it has been noticed that those companies that were suspended completely during the COVID-19 pandemic provided risk disclosures in all categories, while those vital companies that were excluded from the suspension of work wholly or partially were affected little, thus their disclosures were less.

The main motivations of the current study were the great negative impact of the COVID-19 pandemic on various aspects of life in all over the world and to offer a risk disclosure model that can rely on during crisis periods. Therefore; the findings of the current study have many implications. First, the decision-makers should make important amendments to the mandatory disclosure instructions to be more comprehensive in terms of quality and scope. Second, the decision-makers should find radical solutions for the risk disclosure to continue during crises and not to be suspended in any way. Third, the decision-makers in JSC and board of directors should activate the role of risk management committees in corporations. Fourth, managements have to change their disclosure behavior to be more transparent and to include all possible risks. For example, results of current study show very little reporting in competition and expected losses. Finally, the five categories of risks that offered in the current study should be given more emphasis during crises.

In addition to the above mentioned implications, the current study has made several contributions. First,

the current study is considered one of the pioneering exploratory studies that conducted during the COVID-19 pandemic. Second, the current study is considered an important addition to the prior studies in corporate reporting in general and risk reporting in particular. Third, consistent with few prior studies, the current study followed a precise methodology to extract the risk information from each disclosure report. Fourth, the study depends on publicly published disclosure reports, which gives its results high reliability. Fifth, the results of the current study can be easily generalized to all companies in Jordan as the pandemic affected almost the operating activities of all companies. Sixth and more important, the study offers an integrated new disclosure risk model including new risk items.

Despite the small size of the study sample and the exclusion of several publicly listed companies, the current study opens many avenues for future studies. First, future studies can be easily developed the current risk disclosure model by investigating the annual corporate reports of different sectors. Second, the current model of risk disclosure can be easily used as a benchmark to study the future risk disclosure behavior of companies and to determine its level and quality. Third, the current risk disclosure model can be used to develop and construct risk disclosure indexes and to investigate the effect of corporate characteristics and corporate governance variables on such indexes. Fourth, the indexes that can be derived from the current risk disclosure model can be used to identify their effect on dividend policy and the value of shares. Fifth, future study may show if the corporate variables, market variables and governance mechanisms can moderate risk disclosure in crisis. Sixth, future studies may investigate the effect of other crises on the risk disclosure level and other disclosure practices for different time periods in comparison with that of the COVID-19 pandemic. Seventh, future studies may employ several theories to explain the effect of different variable on the risk disclosure practices. Eighth, future study may identify the transparency of risk disclosure by determining the level of the quantitative risk disclosure according to IFRS 7. Finally, future study may investigate the effect of the COVID-19 pandemic on the changes in ownership structure of stocks in ASE and other financial markets. 


\section{References}

Abeysekera, I., \& Guthrie, J. (2005). An empirical investigation of annual reporting trends of intellectual capital in Sri Lanka. Critical Perspectives on Accounting, 16(3), 151-163. https://doi.org/10.1016/S1045-2354(03)00059-5

Ali, M. M., \& Taylor, D. (2014, April). Content analysis of corporate risk disclosure in Malaysia. In 4th Annual International Conference on Accounting and Finance (AF 2014).

Alkurdi, A., Hussainey, K., Tahat, Y., \& Aladwan, M. (2019). The impact of corporate governance on risk disclosure: Jordanian evidence. Academy of Accounting and Financial Studies Journal, 23(1), 1-16

Al-Shammari, B. (2014). Kuwait corporate characteristics and level of risk disclosure: A content analysis approach. Journal of Contemporary Issues in Business Research, 3(3), 128-153.

ASE. (2020). Circulars. Available at: https://www.ase.com.jo/en/circulars

Asongu, S. A. (2013). Post_crisis bank liquidity risk management disclosure. Qualitative research in financial markets, 5(1), 2013, 65-84. https://doi.org/10.1108/17554171311308968

Al- Zoubi, A. A., \& Al-Zoubi, N. Y. (2012). The adequacy of accounting mandatory disclosure under the global financial crisis. A field study in Jordan. Accounting and Management Information Systems, 11(3), 424-441.

Dey, R. K., Hossain, S. Z., \& Rezaee, Z. (2018). Financial risk disclosure and financial attributes among publicly traded manufacturing companies: Evidence from Bangladesh. Journal of Risk and Financial Management, 11(3), 50. https://doi.org/10.3390/jrfm11030050

Deumes, R. (2008). Corporate risk reporting: A content analysis of narrative risk disclosures in prospectuses. The Journal of Business Communication, 45(2), 120-157. https://doi.org/10.1177/0021943607313992

Domínguez, L. R., \& Gámez, L. C. N. (2014). Corporate reporting on risks: Evidence from Spanish companies. Spanish Accounting Review, 17(2), 116-129. https://doi.org/10.1016/j.rcsar.2013.10.002

Ellili, N. O. D., \& Nobanee, H. (2017). Corporate risk disclosure of Islamic and conventional banks. Banks \& Bank Systems, 12(3), 247-256. https://doi.org/10.21511/bbs.12(3-1).2017.09

Gulzar, S., Mujtaba Kayani, G., Xiaofeng, H., Ayub, U., \& Rafique, A. (2019). Financial cointegration and spillover effect of global financial crisis: A study of emerging Asian financial markets. Economic Research-Ekonomska Istraživanja, 32(1), 187-218. https://doi.org/10.1080/1331677X.2018.1550001

Haddad, A. E., Sbeiti, W. M., \& Qasim, A. (2017). Accounting legislation, corporate governance codes and disclosure in Jordan: a review. International Journal of Law and Management, 59(1), 147-176. https://doi.org/10.1108/IJLMA-07-2016-0064

Hassan, M. K. (2009). UAE corporations_specific characteristics and level of risk disclosure. Managerial Auditing Journal, 24(7), 668-687. https://doi.org/10.1108/02686900910975378

Hassan, M. K. (2012). A disclosure index to measure the extent of corporate governance reporting by UAE listed corporations. Journal of Financial Reporting and Accounting, 10(1),4-33. https://doi.org/10.1108/19852511211237426

Hemrit, W., \& Ben Arab, M. (2011). The disclosure of operational risk in Tunisian insurance companies. Journal of Operational Risk, 6(2), 69-111. https://doi.org/10.21314/JOP.2011.089

Höring, D., \& Gründl, H. (2011). Investigating risk disclosure practices in the European insurance industry. The Geneva Papers on Risk and Insurance-Issues and Practice, 36(3), 380-413. https://doi.org/10.1057/gpp.2011.13

Ismail, R., Rahman, R. A., \& Ahmad, N. (2013). Risk management disclosure in Malaysian Islamic financial institutions: pre-and post-financial crisis. Journal of Applied Business Research, 29(2), 419-432. https://doi.org/10.19030/jabr.v29i2.7647

JSC. (2019). Instructions of Issuing Companies Disclosure, Accounting and Auditing Standards for the Year 2004. Available at: https://jsc.gov.jo/Links2/ar/key_new_regulations_instructions

JSC (2020). Circulars and Disclosures. Available at: https://jsc.gov.jo/Disclousre.aspx

Lajili, K., \& Zéghal, D. (2005). A content analysis of risk management disclosures in Canadian annual reports. Canadian Journal of Administrative Sciences/Revue Canadienne des Sciences de l'Administration, 22(2), 125-142. https://doi.org/10.1111/j.1936-4490.2005.tb00714.x 
Linsley, P. M., \& Shrives, P. J. (2006). Risk reporting: A study of risk disclosures in the annual reports of UK companies. The British Accounting Review, 38(4), 387- 404. https://doi.org/10.1016/j.bar.2006.05.002

Lungu, C. I., Caraiani, C., Dascalu, C., \& Guse, R. G. (2011). Exploratory study on social and environmental reporting of European companies in crises period. Accounting and Management Information Systems, 10(4).459-478.

MacDonald, S. B. (1998). Transparency in Thailand's 1997 economic crisis: the significance of disclosure. Asian Survey, 38(7), 688-702. https://doi.org/10.2307/2645756

Madrigal, M. H., Guzmán, B. A., \& Guzmán, C. A. (2015). Determinants of corporate risk disclosure in large Spanish companies: a snapshot. Contaduríay Administración, 60(4), 757-775. https://doi.org/10.1016/j.cya.2015.05.014

Mardini, G. H., Tahat, Y. A., \& Power, D. M. (2013). Determinants of segmental disclosures: evidence from the emerging capital market of Jordan. International Journal of Managerial and Financial Accounting, 5(3), 253-276. https://doi.org/10.1504/IJMFA.2013.058549

Marzouk, Mahmoud (2016) Risk Reporting During a Crisis: Evidence from the Egyptian Capital Market. Journal of Applied Accounting Research, 17(4). 378-396. ISSN 0967-5426. https://doi.org/10.1108/JAAR-02-2015-0012

MOF. (2020). General government finance bulletin. Studies and Economic Polices Directorate, 22(4), May 2020. Available at: https://mof.gov.jo/en us/datacenter/financialbulletins/generalgovernmentfinancebulletins/generalgovernmentbulletins2020.aspx

Mokhtar, E., Elharidy, A., \& Mandour, M. (2018). Compliance with IFRs: The case of risk disclosure practices in Egypt. Arab Economic and Business Journal, 13(1), 1-14. https://doi.org/10.1016/j.aebj.2017.12.001

Oliveira, L., Rodrigues, L. L., \& Craig, R. (2006). Firm _specific determinants of intangibles reporting: evidence from the Portuguese stock market. Journal of Human Resource Costing \& Accounting, 10(1),11-13. https://doi.org/10.1108/14013380610672657

Oliveira, J., Rodrigues, L. L., \& Craig, R. (2013). Company risk-related disclosures in a code law country: a synopsis. Australasian Accounting, Business and Finance Journal, 7(1), 123-130. https://doi.org/10.14453/aabfj.v7i1.8

Omar, B., \& Simon, J. (2011). Corporate aggregate disclosure practices in Jordan. Advances in Accounting, 27(1), 166-186. https://doi.org/10.1016/j.adiac.2011.05.002

Probohudono, A. N., Tower, G., \& Rusmin, R. (2013). Risk disclosure during the global financial crisis. Social Responsibility Journal. 9(1), 124-136. https://doi.org/10.1108/17471111311307859

Rashid, A. A., Ibrahim, M. K., Othman, R., \& See, K. F. (2012). IC disclosures in IPO prospectuses: evidence from Malaysia. Journal of Intellectual Capital, 13(1), 57-80. https://doi.org/10.1108/14691931211196213

Saadi-Sedik, T. and Martin, P. (2006). The Jordanian Stock Market: Should you Invest in it for Risk Diversification or Performance?', IMF Working Papers, WP/06/187, International Monetary Fund. https://doi.org/10.5089/9781451864472.001

Sundmacher, M., \& Ford, G. (2006). Operational risk disclosures in financial institutions. Available at SSRN 963244. https://doi.org/10.2139/ssrn.963244

Suwaidan, M. S., Al-Omari, A. M. D., \& Haddad, R. H. (2004). Social responsibility disclosure and corporate characteristics: the case of Jordanian industrial companies. International Journal of Accounting, Auditing and Performance Evaluation, 1(4), 432-447. https://doi.org/10.1504/IJAAPE.2004.006355

\section{Notes}

Note 1. More information can be found on the following website [https://www.ase.com.jo/en]

Note 2. See the website: https://www.ase.com.jo/en/products-services/securties-types/shares 